\title{
Scope and Application of the FIFRA Treated Articles Exemption
}

\author{
Lawrence S. Ebner'1, David A. Webb ${ }^{2}$ \\ ${ }^{1}$ Capital Appellate Advocacy PLLC, Washington, DC, USA \\ ${ }^{2}$ Creosote Council, Valencia, PA, USA \\ Email: davidawebb@aol.com, lawrence.ebner@capitalappellate.com
}

How to cite this paper: Ebner, L.S. and Webb, D.A. (2020) Scope and Application of the FIFRA Treated Articles Exemption. Journal of Transportation Technologies, 10, 16-20.

https://doi.org/10.4236/jtts.2020.101002

Received: October 14, 2019

Accepted: December 9, 2019

Published: December 12, 2019

Copyright () 2020 by author(s) and Scientific Research Publishing Inc. This work is licensed under the Creative Commons Attribution International License (CC BY 4.0).

http://creativecommons.org/licenses/by/4.0/

\section{(c) (i) Open Access}

\begin{abstract}
This paper discusses the U.S. Environmental Agency's potential improper expansion of its authority under the Federal Insecticide, Fungicide, and Rodenticide Act (FIFRA), the federal pesticide statute, to regulate not only the registration, labeling, and use of wood preservatives, but also treated wood products. EPA's oversight of wood preservatives under FIFRA is extensive. In recent years, despite EPA's own Treated Articles Exemption, 40 C.F.R. $\$$ 152.25(a), EPA has moved toward utilizing wood preservative labeling in a way that could impose restrictions on the end use of treated wood. Wood preservative registrant and user groups should be concerned and vigilant about this trend toward regulation of treated wood. At the same time, they should continue to interact with EPA in a constructive manner, in part to ensure that EPA respects its own regulatory boundary between wood preservatives, such as creosote, and treated wood, such as creosote-treated railroad crossties, which are a key component of the nation's transportation critical infrastructure.
\end{abstract}

\section{Keywords}

Creosote, Wood Preservative, Railroad Crossties, Treated Wood, Registered, FIFRA Treated Article Exemption, Critical Infrastructure

\section{Introduction and Nature of the Treated Articles Exemption}

The Treated Articles Exemption-a regulation first published by the U.S. Environmental Protection Agency (EPA) in 1988-provides that "article[s] or substance[s] treated with, or containing, a pesticide to protect the article or substance itself (for example, paint treated [i.e., formulated] with a pesticide to pro- 
tect the paint coating, or wood products treated to protect the wood against insect or fungus infestation)" are "exempt from all provisions" of the Federal Insecticide, Fungicide, and Rodenticide Act (FIFRA). ${ }^{1}$ For more than 35 years, the Treated Articles Exemption has expressly made all FIFRA provisions inapplicable to treated wood.

For the Treated Articles Exemption to apply, the pesticide used to protect the article or substance from antimicrobial or other degradation (e.g., the wood preservative) must be "registered for such use" under FIFRA. ${ }^{2}$ Further, pesticidal claims made in connection with the treated article or substance cannot state or imply any type of antimicrobial or other pest control other than protection of the article or substance itself. ${ }^{3}$

According to 40 C.F.R. $\$ 152.25$, which is entitled "Exemptions for pesticides of a character not requiring FIFRA regulation," preserved wood, and other treated articles or substances, are among the types of "pesticides or classes of pesticides [that] have been determined to be of a character not requiring regulation under FIFRA" (emphasis added). ${ }^{4}$ In other words, the Treated Articles Exemption is based on the notion that treated wood itself-not just the preservatives used to protect the wood-is a "pesticide."

\section{Regulatory History}

Prior to 1988, EPA did not consider treated wood, or other treated articles or substances, to be a "pesticide." Back then, EPA's view was that treated articles and substances are outside the scope of, and thus excluded from, FIFRA. Without explanation, however, the final regulations that EPA issued in 1988 removed treated wood, and other treated articles and substances, from the excluded-by-FIFRA category, and instead classified them as exempt-by-EPA. By changing its position in this manner, EPA asserted its still-current view that treated articles and substances are encompassed by FIFRA's definition of pesticides, but as a matter of EPA regulatory discretion, should be "exempt from all provisions of FIFRA." As a result, treated wood cannot be regulated under FIFRA, for example, by requiring that a label be placed on the treated wood product.

\footnotetext{
${ }^{1} 40$ C.F.R. $\$ \$ 152.25 \& 152.25(\mathrm{a})$.

${ }^{2} I d . \$ 152.25(\mathrm{a})$.

${ }^{3}$ See EPA Label Review Manual (rev. April 2014), ch. 2, pt. IV.B (providing examples of treated articles or substances covered by the Treated Articles Exemption, including treated lumber, and mold or mildew-resistant paint, shower curtains, bathroom caulks, and fabrics; also providing examples of products, such as clothing treated with pesticides to repel insects, that are not exempt); Pesticide Registration Notice 2000-1, pt. I (explaining that antimicrobial-treated consumer products do not qualify for the Treated Articles Exemption if they make public health claims that extend beyond protection of the article itself).

${ }^{4}$ See also FIFRA $\$ 25$ (b), 7 U.S.C. $\$ 136 \mathrm{w}(\mathrm{b})$ (“Exemption of pesticides”).

${ }^{5}$ See 49 Fed. Reg. $37,916,37,937$ (Sept. 26, 1984) (proposed $\$ 152.10$, replacing previous $\$ 162.4$, stating that treated wood, and other treated articles or substances, are "[p]roducts that are not pesticides because they do not have a pesticidal effect" (emphasis added)).

${ }^{6} 40$ C.F.R. $\$ 152.25$.
} 


\section{Labeling}

More specifically, because the Treated Articles Exemption states that treated wood products are exempt from all FIFRA provisions, they do not have to be registered under FIFRA, and are not subject to EPA labeling requirements-provided that the preservatives used to treat the wood are registered and labeled in accordance with FIFRA.

In 1984 EPA had requested public comment on "the possibility of requiring 'downstream' labeling of consumer products treated with pesticides." But in 1985 an EPA administrative law judge held, in a challenge brought by the wood preserving industry, that pressure-treated wood is not a "pesticide" because it does not have a pesticidal effect other than protecting the wood itself. For that reason he ruled that EPA lacked authority under FIFRA to require treated wood to be accompanied by labeling in the form of consumer information sheets. ${ }^{8}$

EPA never again has attempted to require treated wood to be labeled under FIFRA. Indeed, any such requirement-for example, a requirement that treated lumber be accompanied by labeling specifying its allowable uses and the conditions under which it can be installed-would directly conflict not only with the Treated Articles Exemption, but also the EPA administrative law judge's ruling that treated wood is not a "pesticide" subject to FIFRA regulation.

\section{Regulation of Wood Preservatives vs. Regulation of Treated Wood}

During the past decade, the Antimicrobials Division of EPA's Office of Pesticide Programs, in connection with FIFRA-mandated periodic review of all wood preservatives and other registered pesticides (currently called "Registration Review"), has proposed or imposed wood preservative labeling requirements which, in the authors' opinion, blur the line between regulating the application of wood preservatives in pressure-treatment plants-which EPA has authority to do under FIFRA - and regulating the end uses of pressure-treated wood-which EPA's own Treated Articles Exemption precludes.

More specifically, the Antimicrobials Division has asserted that its FIFRA authority to regulate wood preservatives and their labeling for the purpose of protecting the environment enables it to assess and mitigate any environmental risks posed by the end uses of pressure-treated wood. For example, the Antimicrobials Division has suggested that based on testing of treated wood leachate, it has authority under FIFRA to mitigate any potential environmental risks from "in situ" use (i.e., end use) of treated wood. The Antimicrobials Division also contends that under FIFRA, it can utilize wood preservative labeling as a means for specifying, consistent with American Wood Protection Association (AWPA) use classification standards, the types of treated wood commodities that can be produced with a particular preservative. As another example, the Antimicrobials Division has indicated that it has the authority under FIFRA to require certain ${ }^{7} 49$ Fed. Reg. 37,960, 37,969 (Sept. 26, 1984).

${ }^{8}$ See In the Matter of Chapman Chem. Co., FIFRA Docket No. 529 (June 11, 1985). 
wood preservatives' labeling to include a permissible range of retention rates for various types of treated wood commodities.

In the authors' view, EPA cannot, and should not, attempt to utilize wood preservative labeling to accomplish indirectly what FIFRA and/or the Treated Articles Exemption preclude EPA from accomplishing directly: regulating the types of treated wood products that can be produced, and where and how such products can be used by treated wood purchasers. Wood preservative labeling can and does govern the pressure-treatment application of wood preservatives, primarily for the protection of workers in wood treatment plants. The authors believe, however, that in accordance with the Treated Articles Exemption, regulating the end use of treated wood is beyond the proper scope of the wood preservative labeling.

The Antimicrobials Division, in connection with its Registration Review of creosote, has expressly acknowledged that regulating the reuse of creosote-treated railroad ties for residential landscaping purposes is "not subject to regulation by EPA under FIFRA." The sweep of the Treated Articles Exemption, however, is much broader, precluding EPA from regulating the end use of treated wood in any manner after it leaves a pressure treatment plant. The authors believe that EPA is precluded, for example, from-

- Prohibiting or restricting the end use of any type of treated wood product manufactured with a particular preservative;

- Imposing any other condition relating to where, when, or how treated wood can be installed or must be maintained (e.g., in situ wrapping requirements; buffer zone requirements; limitations on the number of poles or piling that can be installed in a given area);

- Requiring any form of labeling of treated wood products, or requiring warning signs or other notifications regarding the presence of treated wood products after they have been installed for their end uses.

\section{Conclusion}

To its credit, the Antimicrobials Division consistently has solicited and considered the views of wood preserving industry representatives. Based on their decades of experience interacting with EPA on wood preservative matters, the authors are optimistic that despite differences with EPA about the scope and effect of the Treated Articles Exemption, industry representatives and EPA can jointly develop practical, mutually satisfactory measures that will continue to protect the environment while preserving the availability and benefits of treated wood.

\section{Author Information}

Lawrence S. Ebner is founder of Capital Appellate Advocacy PLLC, a boutique law firm located in Washington, D.C. Mr. Ebner has been advising and ${ }^{9}$ Creosote Final Work Plan for Registration Review (Sept. 2015) at 20. 
representing members of the wood preserving industry for the past 35 years.

David A. Webb has worked in the wood industry for 55 years in the area wood adhesives, coatings and wood preservatives products. He has been the Administrative Director for Creosote Council for 22 years.

\section{Conflicts of Interest}

The authors declare no conflicts of interest regarding the publication of this paper. 